\title{
Perbandingan Efektifitas Sterilisasi Panas Kering dan Desinfeksi Tingkat Tinggi Teknik Rebus terhadap Pertumbuhan Escherichia Coli
}

Ika Yudianti ${ }^{1}$, Suprapti $^{2}$, Hupitoyo $^{3}$

1,2,3 Jurusan Kebidanan Poltekkes Kemenkes Malang

\begin{abstract}
Abstrak
Mikroorganisme mudah masuk ke dalam tubuh ibu maupun bayi saat persalinan, termasuk Escherichia coli. Terdapat dua metode pemrosesan alat bekas pakai, yaitu sterilisasi panas kering atau desinfeksi tingkat tinggi (DTT) teknik rebus. Tujuan penelitian ini adalah mengetahui perbandingan efektifitas antara sterilisasi panas kering dan DTT teknik rebus terhadap pertumbuhan bakteri E. coli. Desain penelitian adalah studi komparasi. Pendekatan yang digunakan adalah post test only design. Sampel penelitian adalah biakan bakteri E.coli dari saluran kemih, yang diperoleh dari Laboratorium Mikrobiologi Universitas Brawijaya Malang. Setiap metode menggunakan lima batang jarum jahit otot yang dicelupkan dalam biakan E.coli. Sampel kemudian diamati pertumbuhan koloni baru E.coli setiap hari selama tujuh hari. Hasil penelitian menunjukkan bahwa metode sterilisasi panas kering lebih unggul dalam hal lama keadaan bebas bakteri dan rerata jumlah koloni yang tumbuh. Uji hipotesis menggunakan uji $\mathrm{t}$, diperoleh $\mathrm{t}=4,604 ; \mathrm{p}<0,001$ yang sangat bermakna, artinya ada perbedaan efektifitas pada pemrosesan alat menggunakan teknik panas kering dan DTT teknik rebus. Sterilisasi panas kering lebih efektif dalam pemrosesan instrumen bekas pakai.
\end{abstract}

Kata kunci: Desinfeksi tingkat tinggi, E.coli, sterilisasi

Korespondensi: Jl. Besar Ijen 77c Malang, Tlp./Fax. (0341) 558793 e-mail: ikyudmidwife@ gmail.com 



\title{
Comparative Study in Effectiveness of Dry Heat Sterilization and High Level Desinfection by Boiling on the Growth of E. Coli
}

\begin{abstract}
Microorganisms easy entry into the body of the mother and baby during childbirth, including Escherichia coli. There are two methods of processing of used equipment, which is a dry heat sterilization or high-level disinfection (HLD) boiled techniques. The purpose of this study was to determine the effectiveness of the comparison between the dry heat sterilization techniques and DTT boiled on the growth of E. coli bacteria. Design research is a comparative study. The approach used is a post-test only design. The sample is cultured E. coli bacteria from the urinary tract obtained from the Laboratory of Microbiology University of Brawijaya. Each method uses five trunk muscle sewing needle dipped in E.coli culture. Samples were then observed the growth of a new colony of E.coli every day for seven days. The results showed that the dry heat sterilization method is superior in terms of the old free state and the mean number of colonies of bacteria growing. Hypothesis test with $t$ test obtained $t=4,604 ; p<0.001$, which is very meaningful, meaning that there are differences in the effectiveness of the processing tool using the technique of dry heat and DTT boiled techniques. Thus the dry heat sterilization is more effective in processing the used instruments.
\end{abstract}

Key Word: dry heat sterilization , E. coli , high-level disinfection 


\section{Pendahuluan}

Risiko masuknya kuman meningkat ketika terjadi trauma persalinan, misalnya robekan perineum dan atau vagina. Pembuluh darah yang pecah dan jaringan yang terputus merupakan port d'entry bagi kuman maupun bakteri. Kuman maupun bakteri yang menginfeksi pada saat persalinan berpotensi menimbulkan infeksi pada masa nifas. Bila infeksi tersebut tidak mendapat pertolongan yang adekuat maka dapat menimbulkan penurunan kualitas hidup perempuan, atau bahkan mengakibatkan kematian pada masa nifas yang termasuk dalam

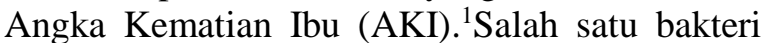
penyebab infeksi luka perineum adalah Escherichia coli (E. coli). E. coli merupakan penyebab utama meningitis pada bayi baru lahir dan infeksi saluran kemih (ISK)., ${ }^{2,3}$ Salah satu bentuk usaha PI adalah dengan pemrosesan alat yang telah digunakan dan akan dipakai ulang (bekas pakai/reusable) dengan metode sterilisasi maupun DTT (Desinfeksi Tingkat Tinggi). Sterilisasi adalah proses penghilangan semua jenis organisme hidup, dalam hal ini adalah mikroorganisme (protozoa, fungi, bakteri, mycoplasma, virus) yang terdapat dalam suatu benda. Proses ini melibatkan aplikasi biocidal agent atau proses fisik dengan tujuan untuk membunuh atau menghilangkan mikroorganisme. ${ }^{4}$

Pelatihan Asuhan Persalinan Normal (APN) maupun Pelatihan Contraceptive Technique Updates (CTU) mengajarkan kepada para bidan untuk mengelola instrumen bekas pakai dengan menggunakan teknik rebus maupun kukus ${ }^{1}$. Teknik ini tidak membutuhkan peralatan yang mahal. DTT teknik kukus/rebus ini harus didahului dengan proses dekontaminasi-cucibilas baru kemudian direbus atau dikukus. DTT dikatakan sangat efektif membunuh bakteri vegetatif, mikrobakteria, virus, dan jamur, namun tidak dapat membasmi spora. Instrumen yang sudah dalam kondisi DTT dapat bertahan paling lama tujuh hari setelah proses rebus/kukus, setelah itu harus kembali dikukus atau direbus. ${ }^{1}$ Saat ini peneliti sering mendapati Bidan Praktik Mandiri (BPM) yang menggunakan sterilisator panas kering untuk pemrosesan alat bekas pakai. Menurut spesifikasi yang tertulis dalam kemasannya, alat tersebut dapat membunuh kuman, bakteri, virus hepatitis B, dan spora. Alat ini membuat peralatan menjadi steril dengan metode ozonisasi. Selain itu alat ini juga dinilai lebih praktis sebab pengguna tidak perlu memindahkan peralatan keluar dari sterilisator hingga saatnya digunakan atau disterilkan ulang, dengan kata lain sterilisator tersebut dapat juga berfungsi sebagai tempat penyimpanan instrumen. Instrumen yang dapat disterilkan dengan alat ini adalah instrumen yang terbuat dari gelas, logam, dan karet.

Teknik sterilisasi panas kering menggunakan alat yang mirip dengan oven kue tersebut tidak diajarkan dalam Pelatihan Asuhan Persalinan Normal. Hal ini disebabkan karena ditengarai alat tersebut tidak dapat menyediakan suhu atau panas yang stabil selama proses sterilisasi berlangsung, sehingga dikhawatirkan tidak memberikan hasil yang optimal. Namun demikian, belum ada bukti penelitian yang menjelaskan perbandingan efektifitas kedua metode tersebut dalam membunuh kuman patogen. Tujuan penelitian ini adalah untuk mengetahui perbandingan efektifitas antara sterilisator panas kering dan DTT teknik rebus terhadap pertumbuhan bakteri E. coli.

\section{Metode}

Desain penelitian ini adalah studi komparasi, yaitu membandingkan efektifitas teknik sterilisasi panas kering dan desinfeksi tingkat tinggi teknik rebus dalam menghambat pertumbuhan bakteri E.coli. Pendekatan yang digunakan adalah post test only design.

Populasi sekaligus sampel penelitian adalah biakan bakteri E.coli yang berasal dari saluran kemih. Biakan diperoleh dari Laboratorium Mikrobiologi Universitas Brawijaya Malang. Guna membandingkan kedua teknik pemrosesan alat, digunakan lima batang jarum jahit otot yang dicelupkan ke dalam biakan E.coli untuk masingmasing teknik, sehingga keseluruhan digunakan 10 batang jarum.

Instrumen penelitian:

1. Teknik sterilisasi panas kering menggunakan sterilisator panas kering baru. Sterilisasi di ruang bagian bawah menggunakan sinar inframerah untuk peralatan yang tahan panas . Tersedia ruang di bagian atas untuk benda yang tidak tahan panas dengan menggunakan teknologi ozon. Lama waktu proses sterilisasi ditentukan oleh pemerataan suhu dalam ruangan (maksimal $150^{\circ} \mathrm{C}$ ). Proses cleaning, desinfeksi, dan pemanasan kering dapat dilakukan dalam waktu bersamaan. 
2. Desinfeksi tingkat tinggi teknik rebus menggunakan sterilisator basah. Material insulator panas terbuat dari glass wool, merupakan bahan yang baik untuk menyekat panas secara maksimal sehingga tidak banyak panas yang terbuang. Menggunakan media air untuk pemrosesan alat.

Urutan kerja:

1. Menyiapkan sepuluh batang jarum jahit otot yang masih baru (steril), satu buah pinset steril, dua buah kom steril bertutup yang telah diberi label sesuai teknik, sebuah tromol, alat pelindung diri (sarung tangan, jas lab, kacamata, alas kaki), serta pengukur waktu (jam).

2. Menyiapkan sterilisator panas kering dan sterilisator basah. Sterilisator panas kering dinyalakan sampai suhu yang diinginkan tercapai $\left(150^{\circ} \mathrm{C}\right.$ indikator merah menyala). Mengisi sterilisator basah dengan air kran sampai tanda batas dan menyalakannya hingga air mendidih $\left(100^{\circ} \mathrm{C}\right)$.

3. Mengambil biakan murni bakteri E.coli yang ditampung dalam tabung pembiakan yang tertutup.

4. Satu-persatu dari sepuluh batang jarum jahit otot dicelupkan ke dalam biakan bakteri Hasil E.coli dengan menggunakan pinset hingga seluruh permukaan jarum terkontaminasi, kemudian jarum dimasukkan ke dalam kom masing-masing sesuai dengan label yang sudah ditempelkan tanpa ditutup.

5. Lima batang jarum dimasukkan ke dalam sterilisator panas kering dengan suhu $150^{\circ} \mathrm{C}$ selama 20 menit dihitung setelah suhu yang diinginkan tercapai.

6. Lima batang jarum lainnya dimasukkan ke dalam sterilisator basah berisi air yang sedang mendidih selama 20 menit.

7. Setelah diproses dalam waktu yang telah ditentukan, kedua kom yang berisi jarumjarum tersebut ditutup dan dimasukkan ke dalam wadah tromol yang dikunci rapat kemudian segera dibawa ke Laboratorium Mikrobiologi Universitas Brawijaya.

8. Jarum-jarum tersebut selanjutnya dipindahkan ke dalam cawan petri bertutup, kemudian diobservasi di bawah mikroskop selama tujuh hari untuk mengamati pertumbuhan bakteri E.coli pada masingmasing teknik pemrosesan alat. Hari pertama dimulai keesokan harinya. Selama masa observasi seluruh sampel tetap berada dalam cawan petri lengkap dengan tutupnya.

Tabel 2 Jumlah E.coli pada Sampel Sterilisasi Panas Kering (Koloni/Lapang Pandang)

\begin{tabular}{cccccccc}
\hline $\begin{array}{c}\text { No. } \\
\text { Sampel }\end{array}$ & I & II & III & Observasi Hari & V & VI & VII \\
\hline 1 & 0 & 0 & 0 & 0 & 0 & 0 & 0 \\
2 & 0 & 0 & 0 & 0 & 3 & 3 & 3 \\
3 & 0 & 1 & 2 & 2 & 6 & 6 & 6 \\
4 & 0 & 0 & 0 & 0 & 0 & 0 & 0 \\
5 & 0 & 1 & 2 & 5 & 6 & 6 & 6 \\
\hline
\end{tabular}

Tabel 2 menunjukkan bahwa pada sampel sterilisasi panas kering:

a. Dalam 24 jam pertama setelah pemrosesan alat tidak terjadi pertumbuhan koloni bakteri E.coli pada semua sampel. Pertumbuhan bakteri paling dini dimulai pada hari II setelah pemrosesan alat. b. Terdapat dua sampel yang sama sekali tidak ditumbuhi bakteri maupun jamur sejak hari I s.d. VII setelah pemrosesan alat.

c. Rerata jumlah koloni bakteri E.coli pada tiap sampel adalah tiga koloni.

d. Pada hari VI dan VII setelah pemrosesan alat sudah tidak terjadi pertumbuhan koloni baru bakteri E.coli pada sampel.

Tabel 3 Jumlah E.coli pada Sampel Dekontaminasi Tingkat Tinggi Teknik Rebus (Koloni/Lapang Pandang).

\begin{tabular}{cccccccc}
\hline No. & \multicolumn{7}{c}{ Observasi Hari } \\
\cline { 2 - 8 } Sampel & I & II & III & IV & V & VI & VII \\
\hline 1 & 0 & 2 & 9 & 17 & 32 & 72 & 72 \\
\hline
\end{tabular}




\begin{tabular}{cccccccc}
\hline 2 & $\begin{array}{c}1+\text { hifa } \\
\text { jamur }\end{array}$ & $\begin{array}{c}1+\text { hifa } \\
\text { jamur }\end{array}$ & $\begin{array}{c}1+\text { hifa } \\
\text { jamur }\end{array}$ & $\begin{array}{c}4+\text { hifa } \\
\text { jamur }\end{array}$ & $\begin{array}{c}25+\text { hifa } \\
\text { jamur }\end{array}$ & $\begin{array}{c}26+\text { hifa } \\
\text { jamur }\end{array}$ & $\begin{array}{c}26+\text { hifa } \\
\text { jamur }\end{array}$ \\
3 & 1 & 4 & 6 & 11 & 17 & 18 & 18 \\
4 & 0 & 0 & 0 & 0 & 1 & 1 & 1 \\
5 & 0 & 3 & 4 & 4 & 4 & 4 & 4 \\
\hline
\end{tabular}

Tabel 3 menunjukkan bahwa pada sampel desinfeksi tingkat tinggi teknik rebus:

a. Dalam 24 jam pertama setelah pemrosesan alat sudah terjadi pertumbuhan koloni bakteri E.coli pada dua dari lima sampel.

b. Seluruh sampel ditumbuhi koloni bakteri E.coli, bahkan ada satu sampel yang juga ditumbuhi oleh hifa (morfologi jamur) selain ditumbuhi bakteri E.coli.

c. Rerata jumlah koloni bakteri E.coli pada tiap sampel adalah 24 koloni.

d. Pada hari VII setelah pemrosesan alat, sudah tidak terjadi pertumbuhan koloni baru bakteri E.coli pada sampel.

Menganalisis perbandingan efektivitas sterilisasi panas kering dan DTT teknik rebus terhadap pertumbuhan koloni bakteri $\mathrm{E}$ menggunakan Uji-T. ${ }^{5,6}$ Pada $\alpha 0.01$; df $\mathrm{n}-1$ ( 5 $-1)=4$; didapatkan $\mathrm{t}_{\text {table }}=4,604$. Oleh karena $\mathrm{t}$ hitung (8.67) > $\mathrm{t}_{\text {table }}(4.604)$ maka H0 di tolak, artinya ada perbedaan efektifitas pada pemrosesan alat menggunakan teknik panas kering dan DTT teknik rebus (panas basah).

\section{Diskusi}

Kejadian sepsis berada dalam peringkat ke-3 sebagai kontributor Angka Kematian Ibu (AKI) di Indonesia. Sepsis dapat berasal dari infeksi yang dimulai sejak dalam kehamilan, persalinan, maupun masa nifas. Hal ini menjadi salah satu yang melatarbelakangi pergeseran paradigma asuhan persalinan normal, dari menunggu terjadinya komplikasi dan menanganinya menjadi mencegah terjadinya komplikasi melalui persalinan bersih dan aman. Terdapat lima aspek dasar yang penting dan saling terkait dalam asuhan persalinan yang bersih dan aman yang dikenal dengan Lima Benang Merah, yaitu: membuat keputusan klinik, asuhan sayang ibu dan sayang bayi, pencegahan infeksi, pencatatan, dan rujukan ${ }^{1}$. Salah satu wujud upaya pencegahan infeksi adalah dengan menggunakan instrumen pertolongan persalinan yang bebas dari kuman atau bakteri patogen.
Tiga proses pokok yang direkomendasikan dalam pemrosesan instrumen pertolongan persalinan adalah dekontaminasi, pencucian dan pembilasan, dan desinfeksi tingkat tinggi (DTT) atau sterilisasi. Teknik DTT dapat menghilangkan atau menon-aktifkan mikroorganisme hingga $95 \%$, sedangkan sterilisasi mencapai $100 \%{ }^{1}$. Sterilisasi panas kering menyebabkan oksidasi destruktif terhadap konstituen, denaturasi protein bakteri, dan mempunyai efek toksik pada sel-sel bakteri ${ }^{7}$.

Penelitian ini tidak melakukan langkah dekontaminasi dan cuci-bilas instrumen dengan pertimbangan bahwa sampel yang digunakan masih dalam keadaan steril/baru. Sampel berupa jarum jahit otot yang telah terpapar koloni bakteri E.coli langsung diproses dengan metode sterilisasi panas kering atau DTT teknik rebus. Hal ini dilakukan supaya tidak terjadi bias dan dapat dilakukan justifikasi bahwa hasil yang diperoleh bukan berasal dari langkah dekontaminasi maupun cuci-bilas, melainkan benar-benar merupakan pengaruh langsung dari sterilisasi panas kering atau DTT teknik rebus.

Alat sterilisator panas kering yang digunakan dalam penelitian ini memanfaatkan radiasi sinar inframerah. Sinar inframerah merupakan gelombang elektromagnetik yang berada di antara sinar tampak dan sinar gelombang mikro. Teori mengatakan bahwa sinar dengan panjang gelombang antara $6-14 \mu$ sebagaimana dimiliki sinar matahari pagi pukul 07.00-09.00 berperan penting dalam formasi dan pertumbuhan makhluk hidup. Pancaran sinar inframerah tidak memerlukan media penghantar dan kekuatan daya tembusnya sangat kuat. Sinar inframerah dapat mengaktifkan dan menyeimbangkan sel-sel tubuh, memecah molekul air, mengencerkan darah, menghambat pertumbuhan sel kanker, bakteri, atau jamur (Ananta, 2005).

Observasi terhadap kelima sampel yang diproses dengan teknik sterilisasi panas kering menunjukkan bahwa dalam 24 jam pertama setelah pemrosesan alat tidak terjadi pertumbuhan koloni bakteri E.coli pada semua sampel, sehingga dapat dipastikan bahwa pada 
saat segera setelah proses sterilisasi baru saja dilakukan semua mikroorganisme yang terdapat pada sampel dalam keadaan mati. Dua dari lima sampel sama sekali tidak ditumbuhi bakteri maupun jamur sejak hari I s.d. VII setelah pemrosesan alat. Pertumbuhan bakteri baru terjadi pada hari II setelah pemrosesan alat. Pada hari VI dan VII setelah pemrosesan alat sudah tidak terjadi pertumbuhan koloni baru bakteri E.coli maupun mikroorganisme lainnya pada sampel. Rerata jumlah koloni bakteri E.coli yang tumbuh pada tiap sampel adalah tiga koloni. Hal ini menunjukkan bahwa absorbsi radiasi sinar inframerah oleh sel bakteri E.coli berakibat pada kematian sel yang ditandai dengan tidak adanya atau keterbatasan dalam membentuk koloni. Hampir semua jenis bakteri memerlukan lingkungan yang gelap untuk mencapai pertumbuhan optimal, sehingga adanya radiasi sinar inframerah ini tidak menguntungkan bagi pertumbuhan koloni bakteri ${ }^{8}$. DTT teknik rebus menggunakan autoklaf memiliki keunggulan yaitu: lebih penetratif daripada teknik panas kering sebab dapat membasahi spora dimana kelembaban sangat penting untuk proses koagulasi protein yang menjadi mekanisme kerja utama teknik tersebut ${ }^{10}$.

Sampel jarum jahit setelah diproses dengan sterilisasi panas kering ini berada dalam kondisi kering, sehingga temperatur tinggi (terasa panas) dan kelembabannya rendah (kering). Temperatur yang berbanding terbalik dengan kelembaban lingkungan dapat menghambat pertumbuhan mikroba, sehingga pada hari I dan II setelah pemrosesan hanya sedikit saja koloni bakteri E.coli yang ditemukan. Semakin lama dari waktu pemrosesan alat, temperatur akan semakin turun dan kelembaban juga semakin rendah, sehingga sedikit demi sedikit terjadi pertumbuhan koloni bakteri E.coli baru pada sampel. Hal ini sesuai dengan pendapat Yashmin Sultana bahwa ada beberapa faktor yang mempengaruhi sterilisasi, yaitu: tingkat kekeringan alat yang akan diproses, temperatur dan kelembaban area pemrosesan, susunan alat dalam sterilisator, kondisi sterilisator, protokol perawatan, dan pemilihan metode sterilisasi yang sesuai ${ }^{9}$.

Proses sterilisasi panas kering yang direkomendasikan dalam Buku Acuan Persalinan Normal dilakukan dalam suhu $170^{\circ} \mathrm{C}$ dalam waktu 60 menit, dan peralatan yang telah disterilkan dapat disimpan sampai dengan tujuh hari berikutnya bila disimpan dalam wadah tertutup dan kering. Sedangkan dalam penelitian ini sterilisasi panas kering dilakukan dalam sterilisator panas kering yang berdasarkan spesifikasinya dapat menghasilkan panas maksimal $150^{\circ} \mathrm{C}$ dalam waktu 20 menit. Ketika telah mencapai menit ke-20 alat tersebut akan mati secara otomatis sehingga operator tidak dapat mengatur suhu maupun waktu yang diinginkan untuk pemrosesan alat. Ini menyebabkan operator tidak dapat mengetahui secara pasti apakah suhu telah benar-benar mencapai maksimal ataukah belum. Perbedaan suhu dan lama pemrosesan inilah yang ditengarai mengakibatkan tumbuhnya koloni bakteri E.coli mulai hari ke-2 setelah pemrosesan alat. Apabila sterilisator panas kering dapat mencapai suhu hingga $160^{\circ} \mathrm{C}$ dan suhunya dapat diatur hingga 60 menit dimungkinkan bakteri akan membutuhkan waktu yang lebih lama untuk dapat hidup pada instrumen.

Observasi yang dilakukan terhadap kelima sampel yang diproses secara desinfeksi tingkat tinggi dengan teknis perebusan memberikan hasil bahwa dalam 24 jam pertama setelah pemrosesan alat sudah terjadi pertumbuhan koloni bakteri E.coli pada dua dari lima sampel. Seluruh sampel ditumbuhi koloni bakteri E.coli, bahkan ada satu sampel yang juga ditumbuhi oleh hifa (morfologi jamur) selain ditumbuhi bakteri E.coli. Rerata jumlah koloni bakteri E.coli pada tiap sampel adalah 24 koloni. Pada hari VII setelah pemrosesan alat, sudah tidak terjadi pertumbuhan koloni baru bakteri E.coli pada sampel.

Teknik desinfeksi tingkat tinggi teknik rebus ini adalah satu metode pemrosesan alat yang sering dilakukan oleh bidan yang praktik mandiri sebelum sterilisator kering diperjualbelikan secara luas seperti saat ini. Bidan umumnya menggunakan panci (dalam Bahasa Jawa disebut "langseng") bersusun maksimal tiga tingkat, sehingga bagian dasar dapat digunakan untuk merebus dan dua susun berikutnya dapat digunakan untuk mengukus instrumen. Pada penelitian ini peneliti menggunakan alat yang disebut sterilisator basah, meskipun prinsip kerjanya tidak berbeda dengan panci yang digunakan untuk merebus instrumen. Sampel yang sudah dikontaminasikan dengan koloni E.coli dimasukkan ke dalam sterilisator pada saat air telah mendidih $\left(100^{\circ} \mathrm{C}\right)$ yang ditandai dengan keluarnya asap dari sela-sela sterilisator, selama 20 menit. Sama dengan teknik perebusan 
menggunakan panci, operator dapat mengetahui dengan pasti bahwa suhu $100^{\circ} \mathrm{C}$ telah tercapai, dan dapat menghitung waktu sesuai dengan yang disyaratkan.

Tumbuhnya koloni bakteri E.coli pada waktu yang lebih cepat pada teknik rebus dapat terjadi karena setelah sampel diangkat dari alat perebus kemudian langsung ditutup, sehingga dimungkinkan masih ada sisa-sisa air yang menempel pada sampel. Berbeda dengan sampel pada sterilisasi panas kering yang setelah diproses keadaannya tetap kering. Keadaan basah dan lembab pasca DTT teknik rebus ini menghasilkan temperatur dan kelembaban yang rendah. Lingkungan yang demikian merupakan media yang baik bagi bakteri untuk berkembang biak, sehingga sejak hari I setelah pemrosesan alat sudah ditemukan pertumbuhan koloni bakteri E.coli pada beberapa sampel.

Hasil analisis statistik menggunakan uji-t sampel bebas menunjukkan adanya perbedaan efektifitas yang signifikan pada p 0,01 antara sterilisasi panas kering dan desinfeksi tingkat tinggi teknik rebus dalam mengeliminasi pertumbuhan koloni bakteri E.coli. Secara mikrobiologis perbedaan ini ditunjukkan dengan perbedaan lama instrumen bebas bakteri E.coli di antara kedua metode. Sampel sterilisasi panas kering baru ditumbuhi koloni bakteri E.coli pada hari II observasi, sedangkan sampel DTT teknik rebus sudah ditumbuhi koloni bakteri E.coli sejak hari I observasi. Perbedaan berikutnya dapat dilihat pada rerata jumlah pertumbuhan koloni bakteri baru setiap harinya. Rerata jumlah koloni bakteri E.coli yang tumbuh pada sampel sterilisasi panas kering adalah tiga koloni, sedangkan pada sampel DTT teknik rebus mencapai 24 koloni dan disertai dengan pertumbuhan hifa (jamur). Perbedaan juga terjadi pada waktu dimana koloni baru bakteri E.coli tidak tumbuh lagi. Pada sampel sterilisasi panas kering pada hari VI sudah tidak ditemukan lagi pertumbuhan koloni baru bakteri E.coli, sedangkan pada sampel DTT teknik rebus koloni bakteri E.coli baru berhenti tumbuh pada hari VII observasi.

\section{Simpulan}

Berdasarkan hasil penelitian dan pembahasan yang telah dilakukan pada bab sebelumnya, maka dapat disimpulkan beberapa hal sebagai berikut:
1) Efektifitas sterilisasi panas kering:

a. Sampel bebas dari pertumbuhan bakteri E.coli dalam 24 jam pertama setelah pemrosesan alat.

b. Dua sampel tidak ditumbuhi bakteri E.coli sejak hari I s.d. VII setelah pemrosesan alat.

c. Rerata jumlah koloni bakteri E.coli pada tiap sampel adalah tiga koloni.

d. Pada hari VI dan VII setelah pemrosesan alat sudah tidak terjadi pertumbuhan koloni baru bakteri E.coli.

2) Efektifitas desinfeksi tingkat tinggi teknik rebus:

a. Dua dari lima sampel telah ditumbuhi koloni bakteri E.coli dalam 24 jam pertama setelah pemrosesan alat.

b. Seluruh sampel ditumbuhi koloni bakteri E.coli, bahkan ada satu sampel yang juga ditumbuhi oleh hifa (morfologi jamur).

c. Rerata jumlah koloni bakteri E.coli yang tumbuh pada tiap sampel adalah 24 koloni.

d. Pada hari VII setelah pemrosesan alat sudah tidak terjadi pertumbuhan koloni baru bakteri E.coli pada sampel.

e. Sterilisasi panas kering lebih efektif dalam menghambat pertumbuhan koloni bakteri Escherichia coli bila dibandingkan dengan desinfeksi tingkat tinggi teknik rebus.

\section{Daftar Pustaka}

1. JNPK-KR. Asuhan Persalinan Normal. JNPK-KR; 2008.

2. Entjang, Indan, 2003, Mikrobiologi dan Parasitologi. PT. Citra Aditya Bakti, Bandung.

3. Melliawati R. 2009. Escherichia coli dalam Kehidupan Manusia. Jurnal BioTrends 2009; 4 (1): 10-14

4. Adji, Dhirgo, dkk. Perbandingan Efektifitas Sterilisasi Alhokol 70\%, Inframerah, Otoklaf, dan Ozon terhadap Pertumbuhan Bakteri Bacillus subtilis. Jurnal Sains Veterenaria. 2007; 25 (11)

5. Budiarto Eko, 2001, Biostatistika untuk Kedokteran dan Kesehatan Masyarakat, EGC, Jakarta.

6. Notoatmodjo Soekidjo, 2002, Metode Penelitian Kesehatan, Rineka Cipta, Jakarta.

7. Vinay $\mathrm{P}$, Giridhar Reddy $\mathrm{Y}$, Nikhilanand $\mathrm{H}$, Priyadharsini. Sterilization Methods in Orthodontics A Review. International J ournal of Dental Clinics. 2011; 3 (1): 44-7.

8. Pelczar, Michael J., 2005. Dasar-dasar Mikrobiologi. Penerbit Universitas Indonesia, Jakarta.

9. Bhana N, Zanwar Aarti S, Trivedi V, Jain D. A Review: Steam Sterilisator A Method of Sterilization. Journal Biol Sci Opin. 2013; 1 (2): 138-41.

10. Rao S. Sterilization and Desinfection. Department of Microbiology. JJMMC Davangere. 2008. Tersedia dari www. microrao.com 